\title{
PENGARUH LATIHAN PUSH - UP DAN LATIHAN PULL - UP TERHADAP KEMAMPUAN PUKULAN LURUS OLAHRAGA PENCAK SILAT PADA SISWA EKSTRAKURIKULER SMP NEGERI 1 KOTA BENGKULU
}

\author{
Jaka Saputra \\ Universitas Bengkulu dan email : Jakasaputrabklu12@gmail.com \\ Syafrial \\ Universitas Bengkulu \\ Sofino \\ Universitas Bengkulu
}

\begin{abstract}
Abstrak
Penelitian ini bertujuan untuk meningkatan pukulan lurus setelah diberikan penerapan latihan push-up dan latihan pull-up pada siswa estrakulikuler pencak silat di SMPN 1 Kota Bengkulu. Metode yang digunakan dalam penelitian ini adalah metode eksperimen . Dengan sampel berjumlah 30 orang, dengan desain yang digunakan adalah pre test-pre test group design. Instrumen penelitian ini untuk mengetahui peningkatan pukulan lurus dengan menggunakan tes pukulan lurus olahraga pencak silat. Selisih rata-rata pree tes dan post tes menunjukan adanya perubahan signipikan dari latihan push-up dan latihan pull-up, dimana hasil rata-rata pre test 48,63 dan hasil rata-rata post test 52,8 dengan selisih 4,17 . Teknik analisis data menggunakan uji t. Hasil penelitian diperoleh $t_{\text {hitung }} 12,26$ jika dibandingkan dengan $t_{\text {tabel }} 1,699$, maka nilai $t_{\text {hitung }}>t_{\text {tabel }}$ berarti ada pengaruh yang signifikan dari latihan push-up dan latiha pull-up terhadap kemampuan pukulan lurus siswa ekstrakulikuler di SMPN 1 Kota Bengkulu.
\end{abstract}

Kata kunci : Push-up,Pull-up, Pukulan Lurus.

\begin{abstract}
This study aims to increase the straight punch after being given the application of push-up exercises and pull-up exercises to students in the pencak silat estruculicular at the Bengkulu 1 Junior High School. The method used in this research is the experimental method. With a sample of 30 people, the design used was pre-test pre-test group design. The instrument of this study was to determine the increase in straight blows using the straight punch test of pencak silat. The average difference in pree test and post test showed significant changes in push-up exercises and pull-up exercises, where the results of the pre test average were 48.63 and the post test results were 52.8 with a difference of 4.17. The data analysis technique uses the $t$ test. The results obtained were 12.26 tcs when compared with ttable 1.699, then the tcount> ttable means that there is a significant effect of pushup exercises and pull-up exercise on the straight punch ability of extracurricular students at Bengkulu City 1 Junior High School.
\end{abstract}

Keywords: Push-ups, Pull-ups, Straight Blows. 


\section{PENDAHULUAN}

Pendidikan merupakan salah satu aspek utama sasaran pembangunan bangsa Indonesia yang orientasinya adalah peningkatan Sumber Daya Manusia (SDM) yang berkualitas. Dalam mencapai tujuan pendidikan yang akan melahirkan manusia yang kompetitif sebagaimana yang diharapkan, oleh karena itu tujuan pendidikan jasmani memberi batasan sebagai berikut: pendidikan jasmani merupakan bagian integral dari pendidikan total yang mencoba mencapai tujuan untuk mengembangkan kebugaran jasmani, mental, sosial, serta emosional bagi masyarakat, dengan aktifitas jasmani. Dalam hal pembinaan olahraga kita menyadari bahwa setiap daerah mempunyai potensi yang berbedabeda baik dalam hal pembinaan cabang olahraga, sumber daya manusia, maupun pendanaan, untuk itu daerah harus dapat meningkatkan prioritas pembinaan cabang olahraganya.

Salah satu olahraga yang sangat diminati oleh masyarakat di Provinsi Bengkulu adalah cabang olahraga beladiri yaitu pencak silat. Hal ini dapat dibuktikan dengan banyaknya pesilat Bengkulu yang mengangkat nama provinsi Bengkulu ditingkat Nasional maupun ditingkat Internasional. Berdasarkan pengamatan pada setiap pembinaan olahraga pencak silat di Bengkulu khususnya ditingkat pelajar merupakan kebutuhan dalam meningkatkan prestasi dibidang olahraga baik tingkat Kota, Provinsi, dan tingkat Nasional.

Siswa SMP Negeri 1 Kota Bengkulu sangatlah antusias untuk mengikuti olahraga pencak silat, namun masih banyak siswa yang belum menguasai teknik dasar olahraga pencak silat. Dari beberapa teknik dasar yang ada dalam olahraga pencak silat pukulan lurus merupakan salah satu teknik yang banyak di gunakan saat pertandingan. namun kenyataan di lapangan masih banyak atlet pencak silat melakukan kesalahan pada saat melakukan pukulan lurus disebabkan kurangnya latihan yang mempunyai pengaruh terhadap pukulan lurus tersebut.

Dalam penelitian ini peneliti menitikberatkan pada 2 jenis latihan yakni push-up dan pull-up yang ada kaitannya dengan kemampuan pukulan lurus dalam cabang olahraga pencak silat, oleh karena itu penulis ingin mengetahui seberapa besar " Pengaruh latihan push-up dan latihan pull-up terhadap kemampuan pukulan lurus olahraga pencak silat pada siswa ekstrakurikuler SMP Negeri 1 Kota Bengkulu".

Pencak silat adalah beladiri tradisional Indonesia yang berakar dari budaya melayu dan bisa ditemukan hampir di seluruh wilayah Indonesia. Setiap daerah memiliki kekhasan ciri gerakannya sendirisendiri (Gunawan, 2007:8).

Menurut Mukholid (2004:126)

"Pencak silat adalah cabang olahraga 
yang berupa hasil budaya manusia Indonesia untuk mempertahankan eksistensi (kemandirian) dan integritasnya terhadap lingkungan hidup, meningkatkan iman dan taqwa kepada Tuhan Yang Maha Esa."

Selanjutnya diungkapkan oleh Lubis (2004:1) "pencak silat merupakan salah satu budaya dari bangsa Indonesia. Para pendekar dan pakar pencak silat menyakini bahwa masyarakat melayu menciptakan dan menggunakan ilmu beladiri sejak masa prasejarah, karena pada masa itu manusia harus menghadapi alam yang keras dengan tujuan untuk melawan binatang buas pada akhirnya manusia mengembangkan gerak gerik beladiri."

Dari beberapa teori di atas, dapat disimpulkan bahwa pencak silat adalah seni beladiri yang berasal dari daerah yang bertujuan untuk melestarikan budaya dan sebagai alat untuk mempertahakan diri dari berbagai masalah yang mungkin di hadapi.

Latihan adalah gerakan yang sudah lebih aktif dan melibatkan gerakan yang disiplin untuk melatih bagian tubuh tertentu dengan pengulangan yang cukup (Sutarmin). Latihan adalah aktifitas untuk meningkatkan kualitas fungsi sistem organ tubuh manusia sehingga mempermudah atlet dalam penyempurnaan geraknya (Apta dan Febi, 2015:47). Dan latihan adalah proses dimana seseorang atlet dipersiapkan untuk peforma tertinggi (Bompa dan Gregory, 2009:2). Dari beberapa pendapat di atas maka latihan adalah sesuatu yang dilakukan terus menerus guna memperbaiki atau meningkatkan semua komponen fisik untuk memperoleh hasil yang maksimal.

Pukulan lurus adalah serangan yang menggunakan lengan dengan tangan mengepal,lintasannya lurus ke depan, dengan titik sasaran atas, tengah, dan bawah. (Dr.Johansyah lubis,m.pd). pukulan lurus adalah salah satu teknik serangan dalam pencak silat yang menggunakan salah satu tangan yang memukul lurus ke depan sasaranya dada dan tangan yang satunya menutup arah point yaitu bagian perut ke atas (Erwin Setyo Kriswanto,s.pd.,m.kes). pukulan lurus adalah pukulan lurus seperti pukulan tinju, pukulan ini mengarah ke depan, tangan mengepal dan tangan satunya lagi menutup atau melindungi dada. Muklis (2009:24) mengemukakan latihan push up adalah suatu jenis senam kekuatan yang berfungsi utubuh dalam ntuk menguatkanotot bisep maupun trisep. Sutarmin(2007) Push up adalah mengangkat tubuh dalam posisi tengkurap dengan tumpuan tangan dan kaki. KBBI (Di akses pada 23 agustus 2018 pukul 16.23 wib) push up adalah mendorong tubuh naik turun dengan tangan. Dari beberapa teori di atas dapat disimpulkan bahwa Push up merupakan salah satu latihan beban yang sangat baik di lakukan manfaatnya adalah untuk menguatkan 
otot dada, bahu, lengan dan dapat mengatur pernapasan.

Suherman(2005:12)

Tradisional pull-up bergantung pada kekuatan tubuh bagian atas tanpa berayun. Target latihan murculus latisimus dorsi terutama otot dibagian lengan. Pull up yang mana tujuannya untuk melatih kekuatan otot lengan. Ibrahim(2005:85) Pullup merupakan s alah satu bentuk latihan yang dapat menguatkan otot lengan sehingga dapat bermanfaat pada olahraga yang membutuhkan otot lengan. Wikipedia diakses pada 23 agustus 2018 pukul16.27 pull up merupakan gerakan yang dilakukan dengan bergantung pada sebuah palang besi dan menarik tubuh sampai dagu bisa sejajar atau lebih sedikit dengan palang. KBBI di akses pada 23 agustus 2018 pukul 16.30 pull up adalah sebuah gerakan yang menarik tubuh kita dari posisi menggantung sempurna pada sebuah benda (besi,pohon,dll) hinga tubuh terangkat. Dari beberapa teori diatas dapat disimpulka bahwa pull up adalah suatu gerakan yang dilakukan dengan cara bergantung lalu mengangkat tubuh naik turun hingga dagu sejajar dengan besi atau palang pegangan.

\section{METODE}

Jenis penelitian yang di gunakan dalam penelitian ini adalah metode eksperimen. Metode eksperimen adalah metode yang bertujuan untuk menentukan data yang diperoleh melalui proses pegukuran untuk mendapatkan data yang objektif, kuantitatif dan hasilnya dapat diolah secara statistic dengan tujuan sejauh mana pengaruh latihan push up dan latihan pull up terhadap kemampuan pukulan lurus pada olahraga pencak silat.

Penelitian yang di gunakan adalah metode eksperimen dengan rancangan pre-test dan post-test group (Arikunto,2006:85)

Penelitian ini dilaksanakan di SMP Negeri 1 Kota Bengkulu. Penelitian ini dilaksanakan selama 16 kali pertemuan. Jumlah populasi dalam penelitian ini adalah siswa ekstrakurikuler SMP Negeri 1 Kota Bengkulu yang berjumlah keseluruhan 50 orang. Teknik pengambilan sampel menggunakan teknik purposive sampling. Artinya teknik pengambilan sampel dilakukan secara sengaja sesuai dengan persaratan sampel yang di tentukan. Berdasarkan teknik sampel di atas maka sample dalam penelitian ini berjumlah 30 orang.

Untuk pengumpulan data dalam penelitian ini di lakukan dengan menggunakan test pukulan lurus, Pelaksanaan: Melakukan pukulan lurus pada aba-aba siap "ya" bersamaan dengan stopwatch dijalankan siswa melakukan pukulan lurus sebanyak mungkin dalam waktu 1 menit. Setelah mencapai waktu 1 menit stopwatch dihentikan dan siswa berhenti melakukan pukulan lurus. 
Penilaian: Jumlah pukulan lurus yang benar dihitung berapa kali siswa mampu melakukan pukulan lurus dan hasil tes dicatat dalam blanko penilaian.

Adapun alat dan fasilitas yang digunakan dalam penelitian ini adalah sebagai berikut:

1. Stopwatch

2. Blanko penilaian

3. Lapangan

4. Kamera (alat dokumentasi)

\section{HASIL DAN PEMBAHASAN}

Tabel

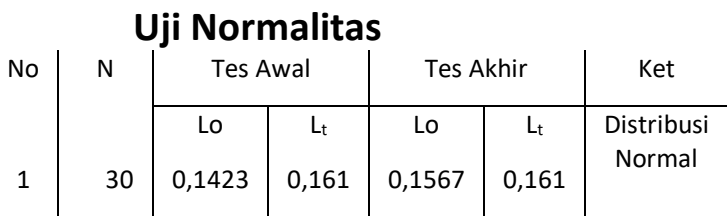

Dari table di atas, diketahui Lo $<L_{\text {tabel, }}$ berarti data yang di ambil dari satu kelompok eksperimen yang teliti mempunyai distribusi Normal.

Tabel

\begin{tabular}{c|c|c|c}
\multicolumn{4}{c}{ Uji Homogenitas } \\
NO & Variabel & $\begin{array}{l}\text { Standar } \\
\text { Deviasi }\end{array}$ & Varians (S2) \\
\hline 1 & Tes Awal & 5,78 & 33,41 \\
\hline 2 & Tes Akhir & 6,9 & 47,61 \\
& \multicolumn{2}{c}{ Dari } & table dapat dilihat
\end{tabular}

bahwa hasil perhitungan varians tes awal (x) adalah 33,41, sedangkan varians tes akhir $(Y)$ adalah sebesar 47,61 .

Hasil rata-rata pretest sebesar 48,63 dan hasil posttest sebesar 52,8 dengan
5. Matras

6. Targe Sasaran (Pencing)

Adapun alat dan fasilitas yang digunakan dalam penelitian ini adalah sebagai berikut:

1. Stopwatch

2. Blanko penilaian

3. Lapangan

4. Kamera (alat dokumentasi)

5. Matras

6. Targe Sasaran (Pencing)

$F_{\text {hitung }}=$ Varians Terbesar varians Terkecil

$F_{\text {hitung }}=47,61=1,43$ 33,41

Dari perhitungan diatas di dapat nilai $F_{\text {hitung }}=1,43$ sedangkan nilai $f_{\text {tabel }}$ pada taraf signifikan $a=0,05=4,17$ $F_{\text {hitung }}<F_{\text {tabel }}$ yaitu 1,43 $<$ 4,17 ini berarti tidak terdapat perbedaan dari masing-masing variabel atau harga varianya Homogen

Tabel Uji T Berdasarkan hasi
awal dan tes akhir pukulan lurus

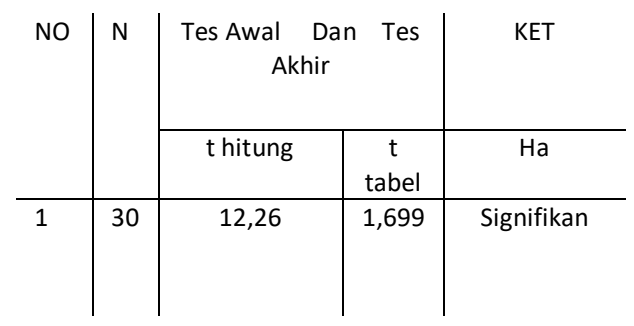

selisih 4,17. Dengan demikian program latihan push-up dan pull-up 
menunjukan adanya peningkatan pada pukulan lurus siswa di SMPN1 Kota Bengkulu. Jadi dapat di katakana bahwa latihan push-up dan latihan pull-up dapat di gunakan sebagai salah satu latihan untuk meningkatkan kemampuan pukulan lurus.

Dari hasil statistik menunjukan bahwa siswa di SMPN1 Kota Bengkulu yang mengikuti latihan push-up dan latihan pull-up selama 16 kali pertemuan mengalami peningkatan pukulan lurus. Dalam memberikan program latihan push-up dan latihan pull-up dengan bermacam variasi, tentunya siswa dapat berlatih dengan gembira dan tidak monoton. Peningkatan pukulan lurus terlihat pada perbandingan perubahan rata-rata prestest dan postest. Dari data yang sudah diperoleh, hasil prestes sebesar 48,63 dan hasil posttest sebesar 52,8 dengan selisih 4,17.

Artinya latihan push-up dan latihan pull-up memberikan pengaruh yang siknifikan terhadap peningkatan kemampuan pukulan lurus. Kemampuan pukulan lurus dapat meningkat apabila latihan di lakukan secara terprogram, dan dilakukan dengan benar.

\section{Simpulan}

Berdasarkan hasil penelitian di atas dapat diperoleh kesimpulan ada pengaruh latihan push-up dan latihan pull-up terhadap kemampuan pukulan lurus olahraga pencak silat pada siswa ekstrakurukuler SMPN1 Kota Bengkulu. Peningkatan pukulan lurus terlihat pada perbandingan perubahan rata-rata prestest dan postest. Dari data yang sudah diperoleh, hasil pretest sebesar 48,63 dan hasil posttest sebesar 52,8 dengan selisih 4,17

\section{Saran}

1. Bagi guru atau pelatih untuk memberikan latihan yang lebih bervariasi lagi sebagai upaya untuk mengurangi kejenuhan latihan.

2. Sebaiknya siswa senantiasa meningkatkan latihan pukulan lurus, untuk mencapai prestasi yang lebih baik.

3. Bagi peneliti yang ingin melanjutkan penelitian ini agar dapat menjadikan penelitian ini sebagai bahan informasi dan penelitian dengan populasi atau sampel yang berbeda dan dalam jumlah yang lebih banyak lagi.

\section{DAFTAR PUSTAKA}

Alexon. (2015). Statistik Untuk Penelitian Pendidikan. Bengkulu : FKIP Universitas Bengkulu

Arikunto, Suharsimi. (2006). Prosedur Penelitian Suatu Pemdekatan dan

Praktik. Jakarta: PT.Rineka Cipta.

Haryo, Ben. (2005). Seniman Beladiri (Martial Artist). Jakarta Selatan: Lubis, Johansyah. (2004). Pencak Silat (Paduan Praktis) Devisi Buku Olahraga. Jakarta: Rajawali Sport. 
Munas IPSI.(2003). Peraturan

Pertandingan Pencak Silat Ipsi. DKI Jaya: Pengurus Besar Ipsi.

Mukholid, Agus.( 2004). Pendidikan Jasmani Kelas 1 SMA. Surakarta: Yudistira.

Muklis.(2009). KesegaranJasmani. Su rabaya: PT Temprina Media Yudistira.

Roji. (2009). Pendidikan Jasmani Olahraga dan Kesehatan Kelas 2 SMP. Jakarta: Erlangga.

Roji. (2009). Pendidikan Jasmani Olahraga dan Kesehatan Kelas 3 SMP. Jakarta: Erlangga.

Rusli, Ibrahim. (2005). Pendidikan Jasmani dan Olahraga. Jakarta: Intan

Pariwara

Suherman, Adang (2005). Asesmen Belajar Dalam Pendidikan Jasmani. Jakarta: Erlangga

Sugiyono. (2000). Statistika Untuk Penelitian. Bandung: Penerbit CV. Alfabeta.

Supardi.(2017). Statistic Penelitian Pendidikan. Depok: Rajawali Pers.
Utomo, Bambang. (2002). Aikido (Seni Beladiri Dan Filosofi ). Jakarta: PT Gramedia Pustaka Utama 